\title{
Experiences of family members of drivers who violate the law against drinking and driving and its repercussions
}

\author{
Vivências de familiares de motoristas infratores da Lei Seca e suas repercussões \\ Experiencias de familiares de conductores infractores de la ley seca y sus repercusiones
}

Indianathan de Kassia Santana Elvira' ORCID: 0000-0003-4827-1523

Sonia Silvia Marcon' ORCID: 0000-0002-6607-362X

Eleine Aparecida Penha Martins" ORCID: 0000-0001-6649-9340

Magda Lúcia Félix de Oliveira' ORCID: 0000-0003-4095-9382

'Universidade Estadual de Maringá. Maringá, Paraná, Brazil. "Universidade Estadual de Londrina. Londrina, Paraná, Brazil.

How to cite this article: Elvira IKS, Marcon SS, Martins EAP, Oliveira MLF. Experiences of family members of drivers who violate the law against drinking and driving and its repercussions.

Rev Bras Enferm. 2021;74(1):e20190466. doi: http://dx.doi.org/10.1590/0034-7167-2019-0466

\section{Corresponding author:}

Indianathan de Kassia Santana Elvira E-mail: indianathan_19@hotmail.com

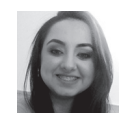

EDITOR IN CHIEF: Antonio José de Almeida Filho ASSOCIATE EDITOR: Mitzy Reichembach

Submission: 09-19-2019 Approval: 10-05-2020

\begin{abstract}
Objectives: to understand the experiences of family members of drivers who violate the law against drinking and driving and the post-penal repercussions. Methods: a qualitative study, with family members of drivers who violated the law against drinking and driving who participated in the Projeto Justiça e Sobriedade no Trânsito de Maringá - PR (Traffic Justice and Sobriety Project in Maringá - PR). Data collection was carried through semi-structured interviews, analyzed through thematic analysis. Results: it was observed in the family members' reports: the suffering of families due to the consumption of alcohol and other drugs; the violation of the law against drinking and driving meaning turning point, with positive and negative changes in the family context; and the meanings of the Traffic Justice and Sobriety Project. Final Considerations: the law against drinking and driving penalties triggered unemployment and financial expenses, but the positive aspects were quitting alcohol use and/or not drinking and driving anymore. The Traffic Justice and Sobriety Project was informed as solidarity and a trigger for changing the offenders' behavior.

Descriptors: Alcohol Intoxication; Family Relationships; Drive Under the Influence; Accidents, Traffic; Public Health Nursing.
\end{abstract}

\section{RESUMO}

Objetivos: compreender as vivências dos familiares de motoristas infratores da Lei Seca e as repercussões pós-penalidades. Métodos: estudo de cunho qualitativo, com membros da famílias de motoristas infratores da, Lei Seca participantes do Projeto Justiça e Sobriedade no Trânsito de Maringá - PR. A coleta de dados foi realizada por entrevista semiestruturada, analisadas mediante análise temática. Resultados: observou-se nos relatos dos familiares: o sofrimento das famílias pelo consumo de álcool e outras drogas; a infração da Lei Seca significando turning point, com mudanças positivas e negativas no contexto familiar; e os significados do Projeto Justiça e Sobriedade no Trânsito. Considerações Finais: as penalidades da Lei Seca desencadearam desempregos e gastos financeiros, mas os aspectos positivos foram a cessação do uso de álcool e/ou não dirigir mais embriagado. O Projeto Justiça e Sobriedade no Trânsito foi informado como solidário e um gatilho para mudança de comportamento dos infratores.

Descritores: Intoxicação Alcoólica; Relações Familiares; Dirigir Sob a Influência; Acidentes de Trânsito; Enfermagem em Saúde Pública.

\section{RESUMEN}

Objetivos: comprender las experiencias de los familiares de conductores infractores de la Ley seca y las repercusiones después de las sanciones Métodos: estudio cualitativo, realizado con familiares de conductores infractores de la Ley Seca participantes del Proyecto Justicia y Sobriedad en el Tráfico de la ciudad de Maringá, Paraná. La recolección de datos se llevó a cabo una entrevista semiestructurada, analizadas mediante análisis temático. Resultados: se observó en los relatos de los miembros de la familia: el sufrimiento de las familias por el consumo de alcohol y otras drogas; la violación de la Ley Seca que significa un punto de inflexión, con cambios positivos y negativos en el contexto familiar; y los significados del Proyecto Justicia y Sobriedad en el Tráfico. Consideraciones Finales: las penalidades de la Ley Seca provocaron desempleo y gastos financieros, pero hubo aspectos positivos como el cese del consumo de alcohol y/o el no conducir más en estado de embriaguez. El Proyecto Justicia y Sobriedad en el Tráfico es tenido como solidario y como detonante para cambiar el comportamiento de los infractores.

Descriptores: Intoxicación Alcohólica; Relaciones Familiares; Conducir Bajo Influencia; Accidentes de Tránsito; Enfermería en Salud Pública. 


\section{INTRODUCTION}

Harmful use of alcohol is responsible for approximately 3.3 million deaths every year, and $5.1 \%$ of the global disease burden is due to alcohol consumption ${ }^{(1-3)}$. Its implications are not restricted to the individual consumer, but it extends to all members of the family nucleus and society, with social and economic damage ${ }^{(4-6)}$.

Families of drug users, exposed to problematic situations, experience psychological suffering, which causes them to face daily challenges, such as guilt, depression, social abandonment, and anxiety. The suffering experience interferes with relationships and family life, causing tension by trying to resist the situation ${ }^{(5,7-9)}$. A study on the repercussions of events related to alcoholism in the lives of these families, would assist in the understanding of this phenomenon, contributing to the prevention, users' treatment and rehabilitation, besides supporting response strategies focused on the family context ${ }^{(10)}$.

Among the several problems resulting from the harmful use of alcoholic beverages, traffic accidents fill a prominent position ${ }^{(11-13)}$. According to the World Health Organization, due to its sedativehypnotic characteristic, alcohol has a strong influence on traffic accidents, which is why it was considered an "accident factor", that is, it directly affects the skills of those who drive a motor vehicle $\mathrm{e}^{(1,12-13)}$. Thus, studies point to a clear trend of increased risk for the occurrence of traffic accidents among drunk drivers ${ }^{(14-16)}$.

Brazil has taken actions to discourage the population from driving under the influence of alcohol or any other drugs, implementing federal legislation since the 1990s, which establishes blood alcohol surveillance and imposes penalties on drivers who drive under the influence of alcohol ${ }^{(15,17)}$.

The law against drinking and driving was an important step towards the establishment of more effective policies to fight drinking and driving, as it imposes zero alcohol intake and attention on alcohol intake by drivers ${ }^{(11,17-18)}$. According to this law, drivers under the influence of alcohol will get fines, suspension of the right to drive for 12 months and the vehicle's apprehension, with the risk of imprisonment if there is a traffic crime ${ }^{(17-18)}$.

The experience with the individual who violates the law against drinking and driving, whether it is an acute/binge user or a chronic user ${ }^{(2)}$, weakens family relationships ${ }^{(19-20)}$, because risky attitudes generate traffic violence, consequently fatal victims and physical and emotional sequelae in survivors, affect the offender's family members, who share the consequences of these attitudes, whether financial, psychological or physical(5,7,21-22).

Knowing the consequences of the association of alcohol and motor vehicle driving in the family context ${ }^{(5,21)}$, this study aims to answer the following concerns: How did the family experience the violation by alcohol abuse of a family member? What are the repercussions of the penalties resulting from the violation of the law against drinking and driving on the family?

\section{OBJECTIVES}

To understand the experiences of family members of drivers who violate the law against drinking and driving and the postpenal repercussions.

\section{METHODS}

\section{Ethical aspects}

The project was approved by the Research Ethics Committee Involving Human Beings of the State University of Maringá, meeting the ethical aspects according to Resolution 466/2012 of the National Health Council. The interviewed family members were identified by the letter F, followed by the ordinal number that respects the sequence of the interviews, assuring the participants' confidentiality.

\section{Type of study}

This is a descriptive, qualitative study, to understand the meaning of alcohol use and the violation of the law against drinking and driving in families of offenders, based on Minayo's technique of thematic analysis ${ }^{(23)}$.

\section{Study setting and data source}

Participants were family members of drivers who violated the law against drinking and driving, and were part of the Traffic Justice and Sobriety Project in Maringá, Paraná, and were registered in the Poison Control Center database of the Hospital Universitário Regional de Maringá - $\mathrm{CCl} / \mathrm{HUM}$ as intoxicated by alcohol and other drugs.

The Traffic Justice and Sobriety Project of the First Criminal Court of Maringá was implemented in 2016. It is an educational intersectoral project, based on Law 13281/2016, that carry out activities for the offending driver who was fined for drunk driving, as an alternative penalty of the provision of services in health centers $^{(19,24)}$, aimed at contributing to the change the offender's behavior and with the decrease of reoffending of alcohol in traffic.

The Project's activities are carried out in four phases: court hearing; participation in a meeting/workshop, which addresses aspects of defensive driving, with a primary focus on drunk driving and information for helping in health services; provision of services to assist victims of accidents treated in the health services/ hospitals involved in the Project, with a workload of 30 hours; and evaluation of the effectiveness on the activities performed.

The first study scenario was the $\mathrm{CCl} / \mathrm{HUM}$, for the selection of the epidemiological records of Toxicological Occurrence of Alcohol Intoxication and/or Other Drugs - OT/IA of the offending drivers, who are reported through the University Extension Project Toxicovigilância e Busca Ativa de Casos e Educação em Saúde (Toxicovigilance and Active Search of Cases and Health Education), filled in meetings/workshops of the Traffic Justice and Sobriety Project. Drivers were considered intoxicated if their alcohol intake was chacked by an alcohol meter or signs of intoxication.

The following inclusion criteria for the study were considered: drivers approached by the Military Police in cases of traffic accidents or traffic inspections of different types; participants of the Traffic Justice and Sobriety Project in 2017; and who lived in the city of Maringá - PR. Offending drivers with incomplete addresses were excluded from the $\mathrm{CCl} / \mathrm{HUM}$ records.

After selection, the second scenario of the study was the home of the offender/family member, to conduct a semi-structured 
interview. The following inclusion criteria for family members were used: being 18 years of age or older; and living with the offending driver, playing the role of a supporter/caregiver in the life of this family member. Family members of offenders who had not completed the four phases established by the Traffic Justice and Sobriety Project were excluded.

A total of 115 records of offending drivers met the criteria for inclusion in the survey and 30 OT/IA records were randomly separated for access to families. Eight family members were interviewed effectively, using the theoretical saturation criterion for dimensioning the sample, supported by the saturation of the speeches and the research objective achieved ${ }^{(25)}$.

\section{Data collection}

Data collection was carried out from October to November 2018, using interviews through a semi-structured script, with sociodemographic questions of the offender and family members, problems related to drug use and about the violation. The interviews were conducted in full by the main author, recorded on audio and guided by the questions: Talk about what it is like for you to live with the use of alcohol in your family? What are the repercussions of the penalties of the law against drinking and driving in the life of the offending driver and his family's life?

Home visits were previously scheduled by telephone contact and access to families was through addresses recorded in the OT/ IA forms. There was no prior contact with the participants, and training to conduct the interviews was carried out in research groups. The interviews were conducted in two meetings per family, with an average of 40 minutes each, and in three interviews, in addition to the participant and interviewer, another family member was present, according to the interviewee's request.

\section{Data organization and analysis}

For the analysis of the relative's interview, the interviews were listened to, respecting the period of not exceeding three days after the meeting. The responses to the triggering questions were transcribed in full, typed into a text document using Microsoft Office Word 10.0.

The results were analyzed using Minayo's thematic analysis technique ${ }^{(23)}$, following the phases of pre-analysis, material exploration and treatment of results/inference/interpretation.

In the pre-analysis, an attempt is made to make a comprehensive reading of the selected material, exhaustively, reaching deeper levels, so the author is saturated with the material. In the second phase, the exploration of the selected material is carried out, the analysis itself, also called categorization, which comprises making the clippings of the texts in units of records and the classification and aggregation of information in thematic categories, aimed at identifying the nuclei of meanings ${ }^{(23)}$. In the third stage of treatment of the results/inference/interpretation, we seek to highlight the information provided by the analysis, through simple quantification. Thus, the inference is made at an intermediate stage, between analytical treatment and interpretation. Finally, the results obtained are interpreted using the theoretical basis ${ }^{(23)}$.

\section{RESULTS}

The offending drivers were men, half were single, with ages ranging from 23 to 53 years old and an average of 42.0 (SD \pm 6.02 ) and 7.8 $(S D \pm 2.47)$ years of education. The time of alcohol use, reported by the offending drivers, was 19.2 (SD \pm 6.66 ) years and two offenders used illicit drugs associated with alcoholic beverages. Regarding the violation, three drivers were fined by the Military Police in traffic inspections and five were involved in traffic accidents after drinking alcohol.

The family members interviewed were women: two mothers, two wives and four sisters. The age ranged from 22 to 61 years, with an average of $44.4(S D \pm 14.56)$ and education of $9.5(S D \pm 3.60)$ years.

The family members speeches were organized into three themes, emphasizing situations experienced by families and the consequences of the penalties of the law against drinking and driving: Family suffering from the use of alcohol and other drugs; Turning point: positive and negative changes arising from the violation in the life of the offending driver and the family; and Recognizing the importance of the Traffic Justice and Sobriety Project in the offender and families' lives.

\section{Theme 1: Family suffering from the use of alcohol and other drugs}

Chart 1 - Thematic categories and text fragments (speeches) that originated the theme 1, Maringa, Parana, Brazil, 2018

\begin{tabular}{|c|c|}
\hline $\begin{array}{l}\text { Thematic } \\
\text { categories }\end{array}$ & Textual fragments (speeches) \\
\hline Fights & $\begin{array}{l}\text { He assaulted his ex-wife, threatened them, so they sepa- } \\
\text { rated. After that, alcohol abuse became terrible. (F7: sister } \\
\text { of the } 43 \text {-year-old offender, charged in a traffic accident) } \\
\text { We often fight because he comes home every day stressed } \\
\text { and under the influence of alcohol. (F4: wife of the } \\
49 \text {-year-old offender, charged in a traffic inspection) }\end{array}$ \\
\hline $\begin{array}{l}\text { Financial } \\
\text { Spending }\end{array}$ & $\begin{array}{l}\text { The problem was when he used the money that was } \\
\text { for paying bills to buy drinks, that was complicated, } \\
\text { because we depended on that money. (F8: sister of the } \\
43 \text {-year-old offender, charged for a traffic accident) }\end{array}$ \\
\hline Codependency & $\begin{array}{l}\text { My mother and I suffered a lot. We care so much about him; } \\
\text { we never know where he is. We wonder if he ate, if he did } \\
\text { not eat, if someone is going to beat him. My mother is sick, } \\
\text { l am depressed, I cry a lot because of that. (F7: sister of the } \\
43 \text {-year-old offender, charged in a traffic accident) }\end{array}$ \\
\hline $\begin{array}{c}\text { Binge* } \\
\text { and daily } \\
\text { consumption }\end{array}$ & $\begin{array}{l}\text { For me it is difficult, it is always tense, not knowing what } \\
\text { will happen. He's not an alcoholic. The problem is on the } \\
\text { weekend that he drinks a lot with friends. (F3: sister of the } \\
\text { 30-year-old offender, charged in a traffic inspection) } \\
\text { He has a serious problem with alcohol. He should seek } \\
\text { treatment because he cannot do it alone. Since I am } \\
\text { with him, he drinks every day. Is very sad. (F4: wife of the } \\
\text { 49-year-old offender, charged in a traffic inspection) }\end{array}$ \\
\hline Fear & $\begin{array}{l}\text { The biggest problem is an accident with him. We don't want } \\
\text { people to die. The biggest problem is if he dies. (F1: mother of } \\
\text { the 39-year-old offender, charged in a traffic inspection) } \\
\text { The hard part is that you destroy another family, another } \\
\text { innocent life. This is the worst consequence. How are we } \\
\text { going to live with that for the rest of our lives? (F2: sister of } \\
\text { the 49-year-old offender, charged in a traffic accident) }\end{array}$ \\
\hline
\end{tabular}

Note: *Sporadic and excessive consumption in a short period. 
The daily problems from living with the user can cause disorders in the family environment, mainly due to fights and financial expenses to buy alcohol and other drugs. In some families, the user was the primary provider of the home. Furthermore, it was observed that living with a family member who uses alcohol and/ or other drugs generates codependency in these families (Chart 1).

Whether living with occasional alcohol use or abuse, the families expressed the repercussion as always being negative. Family suffering is intense, influenced by the "high doses" ingested on weekends and by daily living with alcohol consumption (Chart 1).

Chart 1 also shows that in addition to testimonies of suffering from alcohol use, the problem of the association of drinking and driving was reported in a meaningful way by families, causing suffering due to the feeling of fear with the possibility that their family member will suffer some physical trauma, sequelae and permanent disability, besides death from a traffic accident. Moreover, the fear concerning the relative, the interviewees expressed fear that their relative would drive under the influence of alcohol and cause some harm to other people, to other families, which they called "innocent people".

\section{Theme 2: Turning point: positive and negative changes from the violation in the offending driver and the family's lives}

Chart 2 - Thematic categories and textual fragments (speeches) that originated the theme 2, Maringa, Parana, Brazil, 2018

\begin{tabular}{|c|c|}
\hline $\begin{array}{l}\text { Thematic } \\
\text { categories }\end{array}$ & Textual fragments (speeches) \\
\hline \multirow{3}{*}{$\begin{array}{c}\text { Unemployment } \\
\text { and financial } \\
\text { expenditure }\end{array}$} & $\begin{array}{l}\text { This violation was devastating, not because it was wrong, } \\
\text { we know that you can't drink and drive... What really hurt } \\
\text { our family was that it caused the loss of his license (National } \\
\text { Driver's License). He was a truck driver, it was his life, he } \\
\text { worked for a good company. (F2: sister of the } 49 \text {-year-old } \\
\text { offender, charged in a traffic accident) }\end{array}$ \\
\hline & $\begin{array}{l}\text { He was very sad about the situation. He spent money } \\
\text { on a fine, on bail and still lost his job. (F8: sister of the } \\
43 \text {-year-old offender, charged for a traffic accident) }\end{array}$ \\
\hline & $\begin{array}{l}\text { It was all very painful, especially losing his job, but you } \\
\text { know that thing that has to happen to see if the per- } \\
\text { son wakes up? (F2: sister of the } 49 \text {-year-old offender, } \\
\text { charged in a traffic accident) }\end{array}$ \\
\hline \multirow{4}{*}{ Turning point* } & $\begin{array}{l}\text { It was after the [traffic] accident [...]. He stopped drinking, } \\
\text { he's been sober forten months, he's trying to get back to his } \\
\text { job as a truck driver. He realized that you can't drink and } \\
\text { drive. It took all this for him to stop drinking. (F8: sister of } \\
\text { the } 43 \text {-year-old offender, charged for a traffic accident) }\end{array}$ \\
\hline & $\begin{array}{l}\text { It think the law against drinking and driving is good, because } \\
\text { if we [his family] care. We cannot resolve the issue of driving } \\
\text { while intoxicated, thepolice can. Nowhe is aware that he can- } \\
\text { not drink and drive [...] Today, he still drinks, continues to drink } \\
\text { the same and exaggerates a lot on the weekend, but now he } \\
\text { always calls someone to drive him, or calls those UBER, just } \\
\text { this happening, it's already good, he just needs to stop drink- } \\
\text { ing. (F3: sister of the 30-year-old offender, charged in a traf- } \\
\text { fic inspection) }\end{array}$ \\
\hline & $\begin{array}{l}\text { I think he got better. He lets [me] drive now and before only } \\
\text { he was driving. He's using a lot of UBER when he goes out } \\
\text { alone and leaves the car with me. (F4: wife of the } 49 \text {-year- } \\
\text { old offender, charged in a traffic inspection) }\end{array}$ \\
\hline & $\begin{array}{l}\text { After that, he doesn't drive drunk anymore. the law against } \\
\text { drinking and driving served as a reality check, both for punish- } \\
\text { ment and for the consequences it has had on our lives. (F5: wife } \\
\text { of the } 44 \text {-year-old offender, charged in a traffic accident) }\end{array}$ \\
\hline
\end{tabular}

Note: *Turning point, a moment when the individual becomes aware of his actions from an impacting event.
The law against drinking and driving was understood and supported by families as an extremely important law, which must be complied with by the offenders, even though they experience difficulties in the family context caused by the charge. These difficulties can be seen, especially, by the driver's unemployment and the financial resources spent to pay fines and other administrative measures (Chart 2).

On the other hand, although the violation was a difficult process experienced by the family, the penalties of the law against drinking and driving were understood, by some family members, as an essential measure in the offending driver's process of awareness, influencing the cessation of alcohol use. Although some offenders persisted to drink alcohol, some families expressed a feeling of relief that the family member no longer took the risks of drunk driving (Chart 2).

\section{Theme 3 - Recognizing the importance of the Traffic Justice and Sobriety Project for the offender and families' lives}

Chart 3 - Thematic categories and text fragments (speeches), that originated the theme 3, Maringa, Parana, Brazil, 2018

\begin{tabular}{|c|c|}
\hline $\begin{array}{l}\text { Thematic } \\
\text { categories }\end{array}$ & Textual fragments (speeches) \\
\hline $\begin{array}{l}\text { Participation } \\
\text { in the Traffic } \\
\text { Justice and } \\
\text { Sobriety } \\
\text { Project }\end{array}$ & $\begin{array}{l}\text { After he performed the activities at SAMU and the } \\
\text { hospital, he changed a lot. One day he told me that he } \\
\text { cried when he saw a [cervical] necklace, the one that he } \\
\text { put around his neck, it was from a child and it was all full } \\
\text { of blood. Then he thought that he could have hurt that } \\
\text { child, he was really upset. (F2: sister of the 49-year-old } \\
\text { offender, charged in a traffic accident) } \\
\text { He had to go to the hospital and help injured people. I } \\
\text { think it was what he needed to improve. Sometimes we } \\
\text { talk and get full of it, but when we think, to be part of that } \\
\text { moment was remarkable. (F3: sister of the 30-year-old } \\
\text { offender, charged in a traffic inspection) }\end{array}$ \\
\hline $\begin{array}{l}\text { Psychosocial } \\
\text { treatment } \\
\text { relapse }\end{array}$ & $\begin{array}{l}\text { After the violation, he participated in the project at the hos- } \\
\text { pital, he was fine for nine months, nine months without } \\
\text { drinking alcohol and without smoking. He is a bricklayer's } \\
\text { assistant, he was working, doing everything right, he was } \\
\text { here near us [...] but then everything came back again. He } \\
\text { ended up selling the car, and as he was barely working now, } \\
\text { he could not buy another one, thank goodness, if he had a } \\
\text { car, he would be driving drunk, because he drinks every day. } \\
\text { (F7: sister of the 43-year-old offender, charged in a traffic } \\
\text { accident) } \\
\text { It was after that that he was hospitalized, I think he reconsid- } \\
\text { ered the situation he was living in, unfortunately he wanted } \\
\text { to leave afterward [from the rehabilitation clinic], and start- } \\
\text { ed using again [drugs], and was arrested for drug trafficking. } \\
\text { (F1: mother of the 39-year-old offender, charged in a traffic } \\
\text { inspection) }\end{array}$ \\
\hline $\begin{array}{l}\text { Importance of } \\
\text { the Project in } \\
\text { rehabilitation }\end{array}$ & $\begin{array}{l}\text { I thought there was too short, it should have been more } \\
\text { hours to participate, because it helps. He came home and } \\
\text { spoke about it. We realized that it was important to him. (F6: } \\
\text { mother of the } 37 \text {-year-old offender, charged in a traffic } \\
\text { accident) } \\
\text { The hours he had to accomplish for services in hospitals were } \\
\text { few. He was shocked by the hurt people [...]. (F3: sister of the } \\
\text { 30-year-old offender, charged in a traffic inspection) }\end{array}$ \\
\hline
\end{tabular}

The interviewees showed support for the Traffic Justice and Sobriety Project, understood by them not as a punishment, but as an educational awareness activity. It was recognized by families as an impacting project, directly influencing offending drivers to rethink the act of driving under the influence of alcohol (Chart 3). 
The families experienced, with their members, the process of participation in the Project and they reproduced the knowledge on this theme, since they mentioned their experiences with the family (Chart 3).

The Project influenced the decision-making for the psychosocial treatment of the offender, although relapses were reported sometime after the end of the activities in the health units. In this way, family members expressed the desire that the activities in the Project would be carried out with a workload over 40 hours, understanding the influence of this period on the offender's rehabilitation process (Chart 3).

\section{DISCUSSION}

The II National Survey of Alcohol and Drugs estimated that $5.7 \%$ of the Brazilian population is dependent on alcohol and/ or marijuana and/or cocaine, that is, in households composed of an average of four people, one is dependent, with more than eight million drug users and 30 million people living with a drug addict ${ }^{(26)}$. These families experience fears and insecurities occurring from the dependence and risk behaviors assumed by their members ${ }^{(5,6-8,27-28)}$.

Relatives of drug users have significantly more chronic physical symptoms, complaints of mental suffering and greater psychosocial difficulties than the average population ${ }^{(21,27-28)}$. Those who suffer most from the negative impact caused by the abuse of alcoholic beverages or illicit substances are women, who are generally responsible for the users' treatment, as a large part of them share the role of "head" of the family and care for the user and the whole family ${ }^{(8,22)}$.

The family members, in general, revealed their daily struggle and confrontation, both because of the direct contact with the user, and because of the feelings of uncertainty, shame, sadness and insecurity concerning the trajectory of their family members ${ }^{(5,21-22,28)}$. Family conflicts, divorces and financial problems due to the money continuously spent to buy alcohol and unemployment are consequences of harmful alcohol consumption ${ }^{(5,21-22)}$. With all the problems happening and experienced by the family, the fear of accidents, aggression and the driver's death is greater than all of these $\mathrm{e}^{(29)}$.

The Brazilian government invests in increasingly rigorous measures for those who take up the risk of drinking and driving ${ }^{(14)}$. Violating traffic laws and taking over driving under the influence of alcohol is considered a very serious violation by the Código de Trânsito Brasileiro - CTB (Brazilian Traffic Code). And those fined for violating the law against drinking and driving are determined to pay 10 times the fine, that is, $\mathrm{R} \$ 2934.70^{(18,24)}$.

Besides the financial cost of the fine, the offending driver commits a traffic crime when he is caught driving a vehicle with a concentration equal to or greater than six decigrams of alcohol per liter of blood or equal to or greater than 0.3 milligrams of alcohol per liter of alveolar air, or if signs of intoxication are detected. The vehicle is apprehended and the driver arrested, if there is no situation of killing or serious bodily injury, the driver can pay bail of up to one hundred minimum wages ${ }^{(18)}$.

The families of the offending drivers, under study here, experienced the penalties of the law against drinking and driving in its negative and positive aspects. The measures of authoritarian are evidenced by families as a necessary attempt for the user to recognize, with greater significance, the consequences arising from drinking ${ }^{(22)}$.

The law was understood as a measure to save lives and prevent traffic accidents caused by the influence of alcohol in the direction of motor vehicles. The families supported the law, recognizing the forthcoming risk of damage to the individual and other families, since most of the charges of its members were for being involved in traffic accidents.

However, the penalties reflected in the family financial condition, considering that many drivers were the main providers. Families highlighted long-term financial consequences and unemployment after the violation, which had an impact on the families lives, both in the financial aspect, as well as in professional and family achievement.

Furthermore, they indicated the law against drinking and driving as a turning point in their family members' consumption of alcoholic beverages. A turning point is a moment when the individual becomes aware of his actions from an impactful, joyful or painful event, and starts to try to stop using the drug ${ }^{(30-31)}$. The violation was the moment that increased the propensity or behaviors in a "transformation" of life change towards the cessation or decrease of damages from the drug use $\mathrm{e}^{(31)}$.

The turning points are not only the cessation of consumption, but the tendency of individuals to move from the compulsive phase of drug use to controlled patterns ${ }^{(30)}$. However, relapses may happen if failure trying to achieve established goals and not taking over life more consciously occur ${ }^{(31)}$.

After cessation of alcohol use, that is, alcohol abstinence, the recurrence rates decrease when the individual is aware of his dependence, determined and committed to changing behavior and have a new lifestyle ${ }^{(31)}$.

Family members acknowledged that harm reduction actions, such as not drinking and driving, although the family member persisted to drink alcohol, should be encouraged, as it reduces stress and suffering in the family. Harm reduction strategies, which aim to identify the presence of a problem, stimulate behavior change and propose strategies for this change to happen ${ }^{(32)}$, have been progressively incorporated into Brazilian drug legislation. Thus, in the last two decades, health policies have recognized the care gap provided to users of alcohol and other drugs that were carried out only in cessation programs ${ }^{(32-33)}$.

The Traffic Justice and Sobriety Project was understood as a harm reduction strategy for families and brought to the home experiences lived by offenders in health units, allowing families to perceive the impact of project activities on the offender, directly influencing awareness of the damage caused by driving under the influence of alcohol.

The desire for the Project to have a longer workload, seems to indicate that families also recognize it as a space for rehabilitation and shows that these families need educational actions and less stricto sensu punitive, so that their families cease the use of alcohol and/or other drugs and adopt healthy lifestyle habits.

In this perspective, more partnerships are required between public health networks with national traffic agencies, in raising awareness among drivers and others involved in traffic. Public 
health networks are closely related to fighting violence in traffic, since harmful alcohol consumption is an important public health problem. Working to promote the health of drug users is closely related to the well-being of their families.

\section{Study limitations}

Although the analysis presented here refers to data that identify only a small part of the problems associated with alcohol intake and driving, the study shows the consequences associated with this practice related to the penalties of the law against drinking and driving, which significantly affect the lives of families living with offending drivers.

As this is a study with families of traffic violators, who participated in a specific local project, we observed limited literature for further comparisons and discussions. However, the originality of the study stands out, which may support other research in diverse contexts.

\section{Contributions to the field of nursing, health, or public policy}

The impact of risky behavior by users of alcohol and other drugs is closely related to nursing actions, recognizing the role of caring through direct contact to the patient and his family. Thus, different learning scenarios make it possible to exercise clinical judgment in their training, by linking teaching and service, to establish relationships in the different settings of the individual, family, and society.

Studying the repercussions of the law against drinking and driving in the family context allows contributing to a better understanding of the problems related to alcohol and driving, besides being able to provide subsidies for the establishment of specific policies and campaigns, highlighting the importance of the link between awareness, prevention and inspection.

\section{FINAL CONSIDERATIONS}

This study highlights the repercussions of the law against drinking and driving penalties in the family environment, reported by families, in their positive and negative aspects. Participants reveal the suffering of families and drivers who violate the law against drinking and driving due to the daily problems caused by drinking, in which we highlight fights, financial problems, prison and fear of death.

The law against drinking and driving penalties was negatively impacted by financial expenses and unemployment after the offense. However, it was also positively recognized as a turning point in the lives of these families, mainly concerning the cessation and/or harm reduction from alcohol use. Family members also reported the meaning of the Traffic Justice and Sobriety Project in their lives, as a harm reduction strategy in terms of not driving under the influence of alcohol.

This study allows reflection on the importance of the family in the process of coping with risky behaviors involving alcohol and driving, and highlights that just punitive laws are important to establish rules on human behavior in traffic, educational projects activities are crucial in making drivers aware of compliance with the law.

\section{FUNDING}

This work was carried out with the support of the Coordenação de Aperfeiçoamento de Pessoal de Nível Superior - Brazil (CAPES) - Financing Code 001.

\section{REFERENCES}

1. World Health Organization (WHO). Global status report on alcohol and health [Internet]. 2014 [cited 2017 Oct 14]. Available from: https:// www.who.int/substance_abuse/activities/gsrah/en/

2. Sanchez ZM. Binge drinking among young Brazilians and the promotion of alcoholic beverages: a Public Health concern. Epidemiol Serv Saude. 2017;26(1):195-8. doi: 10.5123/S1679-49742017000100020

3. Garcia LP, Freiras LRS. Heavy drinking in Brazil: results from the 2013 National Health Survey. Epidemiol Serv Saúde. 2015;24(2):227-37. doi: $10.5123 /$ S1679-49742015000200005

4. Rane A, Church S, Bhatia U, Orford J, Velleman R, Nadkarni A. Psychosocial interventions for addiction-affected families in low and middle income countries: a systematic review. Addict Behav. 2017;74(1):1-8. doi: 10.1016/j.addbeh.2017.05.015

5. Lopes APRT, Marcon SS, Decesaro MN. Abuso de bebida alcoólica e sua relação no contexto familiar. Estud Psicol. 2015;20(1):21-30. doi: $10.5935 / 1678-4669.20150004$

6. Mccann TV, Lubman DI. Stigma experience of families supporting an adultmember with substance misuse. Int J Mental Health Nurs. 2018;27(2):693-701. doi: 10.1111/inm.12355

7. Orford J, Velleman R, Natera G, Templeton L, Copello A. Addiction in the family is a major but neglected contributor to the global burden of adult ill-health. Soc Sci Med. 2013;78:70-7. doi: 10.1016/j.socscimed.2012.11.036

8. Sakiyama HMT, Padin MFR, Canfield M, Laranjeira R, Mitsuhiro SS. Family members affected by a relative's substance misuse looking for social support: who are they? Drug Alcohol Depend. 2014;1(147):276-9. doi: 10.1016/j.drugalcdep.2014.11.030

9. Marcheti MA, Mandetta MA. Criança e adolescente com deficiência: Programa de Intervenção de Enfermagem com Família. Goiânia: AB Editora;2016.

10. Santana C J, Oliveira M LF. Effects of drug involvement on long-term users' family members. Rev Rene. 2017;18(5):671-678. doi: $10.15253 / 2175-6783.2017000500015$ 
11. Malta DC, Berna RTI, Silva MMA, Claro RM, Silva Jr JB, Reis AAC. Consumption of alcoholic beverages, driving vehicles, a balance of dry law, Brazil 2007-2013. Rev Saúde Pública. 2014;48(4):692-696. doi:10.1590/S0034-8910.2014048005633

12. Ribeiro LS. Consumo abusivo de álcool e envolvimento em acidentes de trânsito: resultados da Pesquisa Nacional de Saúde, Brasil, 2013 [Dissertação]. ICICT/Fiocruz;2017[cited 2020 Sep 15]. Available from: https://www.arca.fiocruz.br/bitstream/icict/24843/2/lucas_ribeiro_ icict_mest_2017.pdf

13. World Health Organization (WHO). Strategies to reduce the harmful use of alcohol [Internet]. 2008 [cited 2020 Sep 15]. Available from: https://apps.who.int/iris/bitstream/handle/10665/44395/9789241599931_eng.pdf?sequence=1

14. Damacena GN, Malta DC, Boccoline CS. Alcohol abuse and involvement in traffic accidents in the Brazilian population, 2013. Cien Saude Colet. 2016;21(12):3777-86. doi: 10.1590/1413-812320152112.25692015

15. Ladeira RM, Malta DC, Morais Neto OL, Montenegro MMS, Soares Filho AM, Vasconcelos CH, et al. Road traffic accidents: global burden of disease study, Brazil and federated units, 1990 and 2015. Rev Bras Epidemiol. 2017;20(1):157-70. doi: 10.1590/1980-5497201700050013

16. Leonard EA, Buckley T, Curtis K. Impact of alcohol on outcomes in hospitalized major trauma patients: a literature review. Trauma Nurs. 2016;23(2):103-114. doi: 10.1097/JTN.0000000000000194

17. Presidência da República (BR). Lei n. 11.705 de 20 de junho de 2008. Altera a Lei n. 9.503, de 23 de setembro de 1997, que 'institui o Código de Trânsito Brasileiro', e a Lei n. 9.294, de 15 de julho de 1996, que dispõe sobre as restrições ao uso e à propaganda de produtos fumígeros, bebidas alcoólicas, medicamentos, terapias e defensivos agrícolas, nos termos do § 40 do art. 220 da Constituição Federal [Internet]. Diário Oficial da União;2008 [cited 2017 Nov 05]. Jun 16. 16 de junho de 2008. Available from: http://www.planalto.gov.br/ccivil_03/_ato20072010/2008/lei/l11705.htm

18. Presidência da República (BR). Lei no 13.546, de 19 de dezembro de 2017. Altera dispositivos da Lei no 9.503 , de 23 de setembro de 1997 (Código de Trânsito Brasileiro), para dispor sobre crimes cometidos na direção de veículos automotores. Diário Oficial da União;2018 [cited 2020 Aug 27]. Seção 1. Available from: http://www.planalto.gov.br/ccivil_03/_Ato2015-2018/2017/Lei/L13546.htm

19. Elvira IKS. Vivências e implicações das penalidades da lei seca para o infrator e suas famílias. [Dissertação] [Internet]. Universidade Estadual de Maringá. 2019 [cited 2020 Oct 20]. 114p. Available from: http://www.pse.uem.br/teses-e-dissertacoes/dissertacoes

20. Elvira IKS, Rocha BP, Oliveira MLF. Alcoolemia no trânsito: vivências das penalidades da lei seca no contexto familiar dos infratores. In Anais do II Congresso de Saúde Coletiva da UFPR [Internet];2020 jul. 27 - 31[cited 2020 Oct 20];Curitiba, PR: Biblioteca Digital de Eventos Científicos da UFPR. Available from: https://eventos.ufpr.br/csc/csc20/paper/view/4293

21. Maciel SC, Melo JR, Dias CC, Silva GL, Gouveia YB. Depressive symptoms in family members of drug-addicts. Psicol Teor Prat [Internet]. 2014 [cited 2018 Jun 04];16(2):18-28. Available from: http://pepsic.bvsalud.org/pdf/ptp/v16n2/02.pdf

22. Reis LM, Oliveira MLF. Social vulnerability in families living with long-term addictive behavior. Acta Paul Enferm. 2017;30(4):412-419. doi:10.1590/1982-0194201700061

23. Minayo MC. O desafio do conhecimento: pesquisa qualitativa em saúde. 14. ed. São Paulo: Hucitec;2015.

24. Presidência da República (BR). Lei n. 13.281, de 04 de maio de 2016. Altera a Lei n. 9.503, de 23 de setembro de 1997 (Código de Trânsito Brasileiro), e a Lei n. 13.146, de 6 de julho de 2015[Internet]. Diário Oficial da União;2016 [cited 2019 Jan 27]. Maio 5. Seção 1. Available from: http://www.planalto.gov.br/ccivil_03/_ato2015-2018/2016/lei/113281.htm

25. Minayo MCS. Amostragem e saturação em pesquisa qualitativa: consensos e controvérsias. Revista Pesquisa Qualitativa [Internet]. 2017 [cited 2017 Jul 5];5(7):01-12. Available from: https://editora.sepq.org.br/index.php/rpq/article/view/82/59

26. Laranjeira R, Sakiyama H, Padin MFR, Madruga CA, organizadores. Lenad família: Levantamento nacional de famílias dos dependentes químicos. São Paulo: Instituto Nacional de Ciência e Tecnologia para Políticas Públicas de Álcool e Outras Drogas (INPAD) [Internet]. 2013 [cited 2017 Nov 10]. Available from: https://inpad.org.br/_lenad-familia/

27. Antunes F, Oliveira MLF. The quotidian of family caregivers of alcohol users who required intensive care hospitalization. Cienc Cuid Saúde [Internet]. 2016 [cited 2019 Jan 03];15(1):3-10. Available from: http://periodicos.uem.br/ojs/index.php/CiencCuidSaude/article/view/25153/pdf_1

28. Elvira IKS, Reis LV, Gavioli A, Marcon SS, Oliveira MLF. Esperança de famílias que convivem com comportamento aditivo por tempo prolongado. Rev Enferm C-Oeste Mineiro. 2019;9(2019):e3241. doi: 10.19175/recom.v9i0.3241

29. Santos EL, Simon BS, Schimitd SMS, Machado BP. The reflections of living together with crack users in family relationships. J Nurs Health [Internet]. 2016 [cited 2017 Nov 10];1(1):4-16. Available from: https://periodicos.ufpel.edu.br/ojs2/index.php/enfermagem/article/ view/5959

30. Oliveira LG, Nappo SA. Characterization of the crack cocaine culture in the city of São Paulo: a controlled pattern of use. Rev. Saúde Pública. 2008;42(4):664-71. doi: 10.1590/S0034-89102008005000039

31. Marangoni SR, Oliveira MLF. Triggering factors for drug abuse in women. Texto Contexto Enferm. 2013;22(3):662-70. doi: 10.1590/ S0104-07072013000300012

32. Lima MJ, Oliveira LC, Silva HR, Pereira KR, Nascimento EDS, Costa RG, et al. Intervenção de redução de danos causados por drogas lícitas ilícitas a um individuo em situação de rua. Rev Extendere [Internet]. 2017 [cited 2019 Jan 02];5(1):67-78. Available from: http://periodicos. uern.br/index.php/extendere/article/view/2575/1406

33. Machado LV, Boarini ML. Políticas sobre drogas no Brasil: a estratégia de redução de danos. Psicol Cienc Prof. 2013;33(3):580-95. doi: $10.1590 /$ S1414-98932013000300006 